Chapter 22

\title{
Assessment of the Impacts of Groundwater Overdrafting on Water Quality and Environmental Degradation in the Fares Area, Aswan, Egypt
}

\author{
Mohamed Saber, Omar Ahmed, Esmat A. Keheila, \\ Mohamed Abdel-Moneim Mohamed, Sameh A. Kantoush, \\ Mohammed Abdel-Fattah, and Tetsuya Sumi
}

\begin{abstract}
Groundwater contamination and the environmental impact of groundwater uprising due to overpumping are critical issues in Egypt. The main purpose of this study is to evaluate the groundwater quality and the environmental impacts of groundwater uprising in the Fares area of Aswan, Egypt. The environmental impacts of the uprising groundwater level were investigated through field observations and chemical analyses of the surrounding water resources. The results revealed that the use of flood irrigation systems in the upper, newly reclaimed land area is the main cause of the uprising groundwater levels, which causes remarkable environmental degradation in the urban area. Thirty-three samples were collected and chemically analyzed from three groundwater wells. The chemical characterization of the groundwater at Well 1 drastically changed from $\mathrm{NaHCO} 3$ to $\mathrm{NaCl}$ within a short period of time due to overdrafting. The chemical concentrations of all parameters showed considerable increasing trends and exceeded the standard limits at Well 1. The study stated that the groundwater overdrafting causes extreme changes in the water quality within a very short period of time along with the impacts on the environment. This condition requires attention from decision makers, as the groundwater quality is continuously decreased and the environment is degraded.
\end{abstract}

Keywords Groundwater Quality • Hydrochemical analysis • Overdrafting • Environmental impacts · Groundwater level uprising • Aswan • Egypt

M. Saber $(\bowtie) \cdot$ S. A. Kantoush · T. Sumi

Disaster Prevention Research Institute (DPRI), Kyoto University, Kyoto 123, Japan

e-mail: mohamedmd.saber.3u@kyoto-u.ac.jp

O. Ahmed · E. A. Keheila · M. A.-M. Mohamed

Geology Department, Faculty of Science, Assiut University, Asyut 71516, Egypt

M. Abdel-Fattah

Civil Engineering and Quantity Surveying Department, Military Technological College,

P.O. Box: 262, P.C: 111, Muscat, Oman

(C) The Author(s) 2022

T. Sumi et al. (eds.), Wadi Flash Floods, Natural Disaster Science and Mitigation

Engineering: DPRI Reports, https://doi.org/10.1007/978-981-16-2904-4_22 


\subsection{Introduction}

Groundwater is an important source of fresh water for agricultural, drinking, and domestic uses in many regions of the world (Balachandar et al. 2010). It is estimated that approximately one-third of the world's population uses groundwater for drinking (Nickson et al. 2005). The increase in the population and its needs have led to the deterioration of surface and subsurface waters (Dhiviyaa et al. 2011). In 1999, the United Nations Environment Programme (UNEP) reported that approximately 200 scientists in fifty countries had identified water scarcity as one of the two most worrying problems for the new millennium (United Nations Environmental Program (UNEP) 2002). Groundwater is a major source of drinking water worldwide and plays a vital role in maintaining the ecological value of many areas (IPCC 2001). The reliability of groundwater for drinking lies not only in its widespread occurrence and availability but also in its consistently good quality, all of which makes it an ideal source of drinking water (UNESCO 2000).

In general, the motion of groundwater along its flow paths below ground surfaces increases the concentration of chemical species (Freeze and Cherry 1979; Domenico and Schwartz 1990; Kortatsi 2007), and the concentrations of dissolved ions in groundwater are controlled by the nature of geochemical reactions, lithology, residence time, groundwater flow, solubility of salts, and human activities. Moreover, groundwater quality is influenced by natural geochemical processes, ion exchanges, and human activities such as agriculture, sewage disposal, and the creation of industrial wastes. Recently, several studies have focused on monitoring groundwater quality and evaluating domestic and agricultural activities worldwide (Mitra et al. 2007; Jain et al. 2009; Hakim et al. 2009; Nagarajan et al. 2010). In Egypt, groundwater quality evaluation and monitoring have received little attention; therefore, these types of analyses are urgently needed in Egypt to understand the hydrochemistry and quality changes of groundwater.

The World Health Organization calculated that up to $80 \%$ of all sicknesses and diseases in the world are products of inadequate sanitation, polluted water, or water scarcity (WHO 2004). Among fresh waters, only approximately 5\% are readily available for beneficial use (Usharani et al. 2010). The microbiological quality of water is measured by analyses and enumerations of indicator microorganisms (Briancesco 2005). Groundwater is a crucial source of drinking water, and its quality has recently become vulnerable due to a combination of over-abstraction and microbiological and chemical contamination (Pedley and Howard 1997; Reid et al. 2003; Aydin. 2007). Additionally, worldwide, 780 million people do not have access to high-quality water sources, and an estimated 2.5 billion people, half of the developing world, lack access to proper sanitation (WHO/UNICEF 2012). Approximately $88 \%$ of deaths due to diarrheal illness are attributable to low-quality water, improper sanitation, or poor hygiene (Liu et al. 2010). Diarrheal diseases (e.g., cholera) kill more children than AIDS and malaria, making them the second leading cause of death among children under 5 years old (Liu et al. 2010). More than 1.5 million children die every year from diarrheal diseases (Fenwick 2006). 
The most important pathogenic bacteria and viruses that might be transported in groundwater are Salmonella sp., Shigella sp., Escherichia coli and Vibrio sp., and the hepatitis virus, Norwalk virus, echovirus, poliovirus, and coxsackie viruses (Corapcioglu and Haridas 1984; Craun 1984; Gerba et al. 1981).

Although water is a renewable resource, the population of Egypt tripled in 50 years, from 19 million individuals in 1947 to approximately 62 million individuals in 1996, and it is expected to be approximately 95 million by 2025 . Consequently, the water demand will increase daily; however, Egypt's share of Nile River water is fixed. Egypt's quota of Nile River water is 55.5 billion cubic meters, so the availability of surface water will become inconvenient, insufficient, or infeasible for consumption with an increasing population, considering that groundwater exhaustion occurs faster than its percolation back into the ground (Trivedy et al. 1987); this effect leads to the increasing importance of groundwater every day. In Egypt, $87.7 \%$ of the total water is consumed by agriculture and 5.4\% is consumed by industry, while the total human consumption accounts for $6.8 \%$ of the total water use (Shalaby 2005). One important issue involves redistributing the population over a large area because $99 \%$ of the population is concentrated in the Nile River valley and delta. Therefore, the Egyptian government is determined to increase agricultural production by increasing cultivated areas through the reclamation of new lands in the desert. This particular practice would not only increase the total cultivated area in Egypt but would also relieve the population stress on the narrow Nile Valley land and create new employment opportunities. This paper is a part of a comprehensive study of groundwater quality evaluations and modeling considering the environmental impacts that occur at different locations in Egypt due to the vulnerability of the pollution and the importance of water resources; hydrochemical and bacteriological analyses have been conducted in the Manfalut District of Assiut, Egypt, and researchers have concluded that approximately 55\% of the local groundwater wells are not suitable for drinking due to the impacts of chemical and bacteriological contamination (Saber et al. 2014).

During the last decade, a number of inhabitants (farmers) started to reclaim and cultivate new lands in the Fares area of Aswan Governorate, Egypt, because these inhabitants depend mainly on agriculture as a main source of income. Consequently, most of the reclamation and irrigation systems in this region have been implemented without any prior scientific or hydrological surveys. For instance, flood systems are used for irrigation from groundwater wells, which could be very risky for groundwater storage in this area. Therefore, the objectives of the present study are (a) to evaluate the quality of the groundwater in the Fares area of Aswan, which covers both the Nile floodplains and desert fringes, (b) to understand the changes in groundwater chemistry that occur due to groundwater overdrafting, and (c) to maintain the sustainability of groundwater, especially as the groundwater demand in the reclaimed land increases continuously, which may influence the efficiency of the water supply both qualitatively and quantitatively. The evaluation of groundwater quality in the Fares area is challenging, mostly due to the low numbers of existing groundwater wells and a lack of data. Additionally, in the study area, the most critical issue is that the lowland areas suffer from groundwater 
uprising, resulting in the loss of many mango gardens and gardens of other fruits as well as damage to the infrastructure of the city, such as houses and buildings. Additionally, the uprising of groundwater has a large environmental impact in terms of health threats and the spread of diseases due to the pollution of surface water. Thus, one of the most important objectives of this study is to assess and evaluate the environmental impacts in the target area that results from the excessive use of groundwater for irrigation.

\subsection{Study Area}

The study region (Fig. 22.1) is located on the west bank of the Nile River, northwest of Aswan city. The area extends between latitudes $24^{\circ} 34^{\prime}-24^{\circ} 40^{\prime} \mathrm{N}$ and longitudes $32^{\circ} 51^{\prime}-32^{\circ} 55^{\prime} \mathrm{E}$. It covers an area of approximately $25 \mathrm{~km}^{2}$. The total population of the area is approximately 15,000 inhabitants, and most of the economic activity in the study area involves agriculture. The irrigation system is mostly fed by groundwater as well as the canal system. The selected area comprises an arid region that is characterized by a hot and dry climate with no rainfall in summer and a mild climate with rare rainfall in winter. In winter, the average temperatures range from $11{ }^{\circ} \mathrm{C}$ at night to $25{ }^{\circ} \mathrm{C}$ during the day, and the average summer temperatures range from $25^{\circ} \mathrm{C}$ at night to $40{ }^{\circ} \mathrm{C}$ during the day.

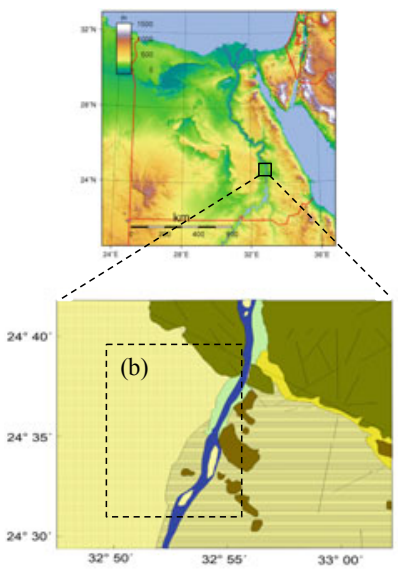

(a)

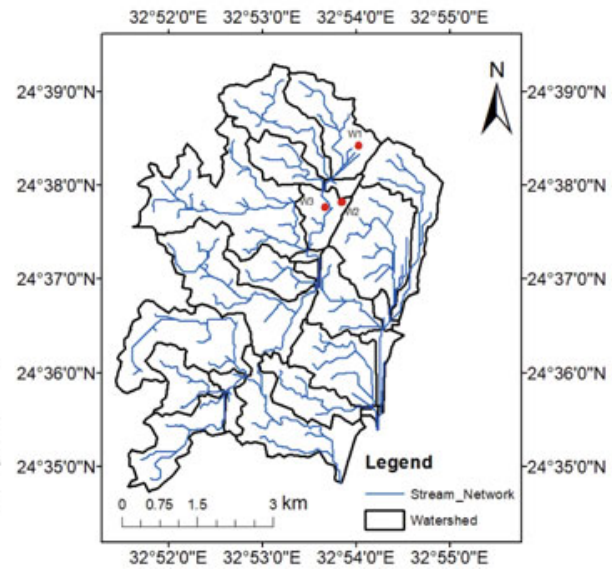

(b)

Fig. 22.1 a Location and geological map of the Fares area in Aswan, Egypt (modified after the new geological map of Egypt (Failed 1977; EGPC and Conoco 1987), b developed watershed and stream network of the target 


\subsection{Geological and Hydrogeological Setting}

The study area is located in Aswan Governorate, in the western desert and east of the El-Gallba plain (the western part of the Kom Ombo basin) and north of the Wadi of El-Kubanyia. Geologically, it is situated within the African platform; thus, its tectonic framework is related to the last African orogenic belt (Said 1962; Abd El-Razik and Razavaliaev 1972). The borehole lithology in the Fares area collected from a field survey indicates that Quaternary sediments comprising sands constitute the upper layer and are underlain by shaley sand, sandy mud, and medium- to coarse-grained sand, followed by coarse-grained sand and gravels saturated with water.

The area is characterized by gentle northeast slopes oriented toward the Nile River. Additionally, on the western side of the Nile River, there is a wide plain occupying approximately $20 \mathrm{~km}^{2}$, which is bordered by the western high plateau as well as some sand dunes and reclaimed agricultural land areas. There is also a narrow flat area east of the Nile River bordered by a limestone plateau to the east (Ministry of Water Resources and Irrigation (MWRI) 2007). The topographic features were constructed from surface elevation data during a field trip, showing that the average elevation varies from approximately $86 \mathrm{~m}$ above sea level in the eastern part (urbanized city) to approximately $123 \mathrm{~m}$ above sea level in the western part (reclaimed lands). The study area is occupied by sedimentary rocks (Fig. 22.1) belonging to the Upper Cretaceous and Quaternary Periods, which represent the main water-bearing unit in the Nile Valley region; these deposits belong to the Proto-Nile River system occupying the present Nile basin and are made up of gravels and coarse-grained sand embedded in a brown matrix (Said 1962, 1981; Ministry of Water Resources and Irrigation (MWRI) 2007).

Climatologically, the area under investigation comprises a part of the arid belt of North Africa, which is characterized by long, hot summers and short, warm winters with rare rainfall. Based on the climatic data obtained from the Egyptian Meteorological Authority and from previously published studies, the average maximum air temperature during the period from 1998 to 2012 ranged between $28.8^{\circ} \mathrm{C}$ in winter and $42.4{ }^{\circ} \mathrm{C}$ in summer, and the average minimum temperature ranged between $10.7^{\circ} \mathrm{C}$ and $27.1^{\circ} \mathrm{C}$ in winter. The average annual rainfall value over the area in winter is $0.1 \mathrm{~mm}$ and in spring is $0.5 \mathrm{~mm}$; rainfall in autumn is rare. The relative humidity differs from season to season: in the winter, it ranges between 33.9 and $40.3 \%$; in the autumn, it ranges from 26.5 to $30.1 \%$; and the relative humidity decreases in both spring and summer to range between 15 and $20.7 \%$. In the spring and summer, the average wind velocities are 13.7 and $14.4 \mathrm{kt}$, respectively, whereas in autumn and winter, they are 13.1 and $12.2 \mathrm{kt}$, respectively. The calculated aridity degree for Aswan Governorate based on the Emberger formula (Emberger 1951) is 0.0153, which indicates typical desert climatic conditions. 


\subsection{Environmental Investigations}

Predicting the environmental consequences of human development and planning appropriate measures to eliminate or reduce these adverse effects and to augment positive effects are formal processes (Dougerty et al. 1995). Groundwater plays an important role in satisfying the water requirements of most arid and semiarid areas. Thus, groundwater sustainability and the preservation of groundwater quality should receive priority attention to enable countries to plan water and land use in an integrated manner and to avoid irreversible environmental damage. Land reclamation projects have been undertaken to increase Egypt's arable land area. In the area of Fares, Aswan, the environmental situation is drastically represented by the rising groundwater level, resulting in environmental impacts on agricultural fields and the houses and property of humans. In this study, several field observations were conducted to understand and determine the reasons for groundwater uprising. The study area is suffering from groundwater uprising, which has affected the urbanized Fares area by causing the collapse of approximately 64 resident homes; 500 homes have been damaged, and the tombs of the city have been affected, forming swamps and covering the low-lying agricultural areas (Fig. 22.2A, B, C, $\mathrm{D}$, and E). Consequently, approximately 500 acres of farmland have been damaged, and groundwater uprising has hindered the establishment of the Kalabsha Corridor project (Fig. 22.2F), which is considered a vital project in Aswan Governorate.

During a field trip, we conducted observations of the affected regions as well as a discussion with the people of Fares to see the extent to which they are suffering from the problem of groundwater level uprising. We found that the impacts of groundwater uprising in the Fares area started in 2010, one year after agriculture activities such as flood irrigation began in the new reclamation areas (upstream area) in the desert. This is also confirmed by the changes in land use and agricultural lands observed from Google Earth images between October 2009 and August 2010, showing the expansion of agricultural lands (Fig. 22.3) within one year and, consequently, the expansion of development in the low-lying areas (agricultural farms, houses, and most infrastructure).

Farmers are using flooding systems to irrigate the new reclamation lands, and unfortunately, these systems are used unwisely and excessively and are undoubtedly a principal cause of the increase in the groundwater level. In addition, these lands have no drainage system. The excessive water from the flood irrigation systems flows directly to the downstream area, which is identified and confirmed in the developed watershed of the area (Fig. 22.1b). The watershed of the study area was developed by GIS and a digital elevation model and illustrates that the water flow direction is from the reclamation area (upper lands, land elevation is $123 \mathrm{~m}$ ) toward the impacted area in the lowlands (land elevation is $86 \mathrm{~m}$ ).

Chemical analysis was performed to determine the source of the uprising groundwater in the affected regions and to determine whether this effect originates from the surface drainage system (Nile River) or from the groundwater wells. Water samples were collected and analyzed (Table 22.1) from the impacted areas and from 

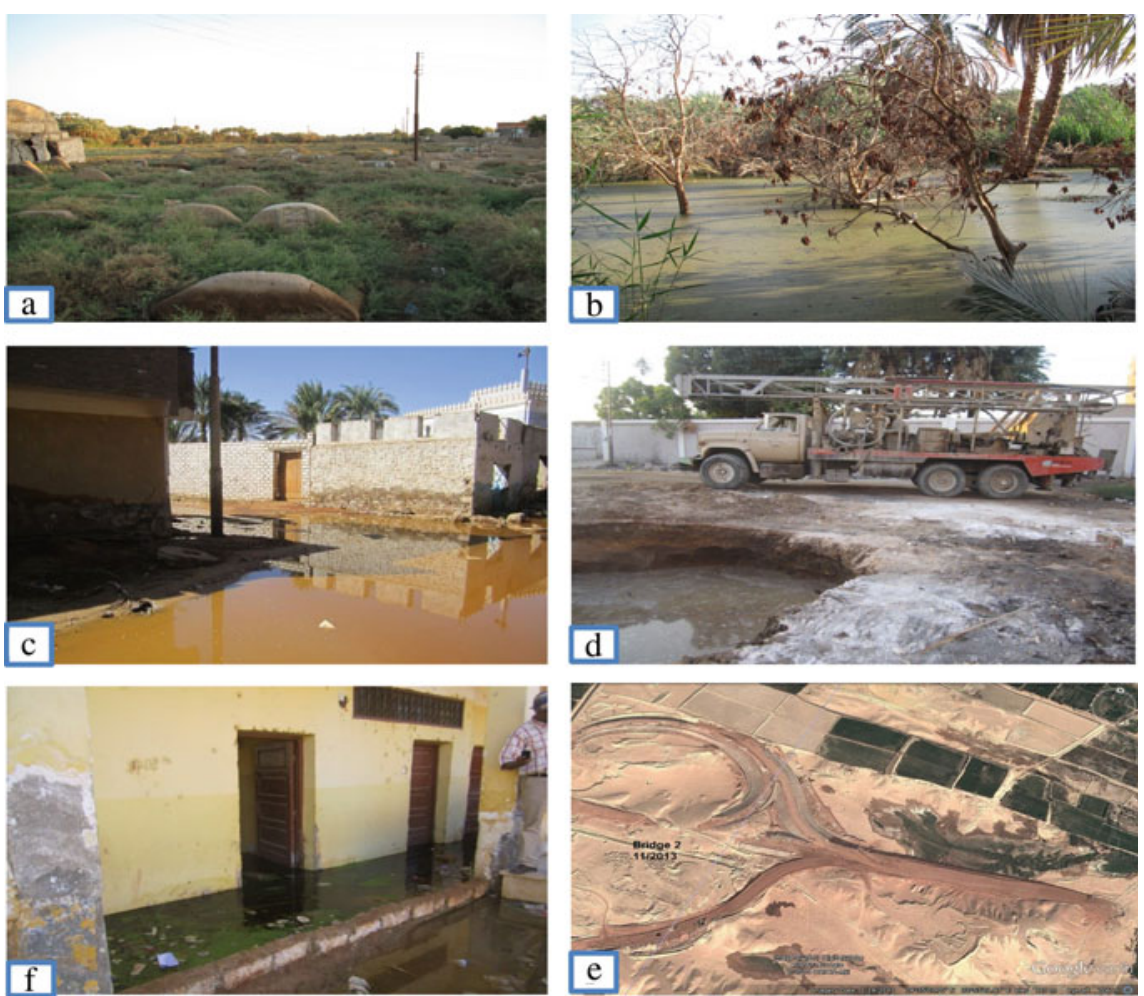

Fig. 22.2 Field observations show the regions affected by groundwater uprising: A graveyard in the Fares area (15/4/2013), B affected mango tree farm (water depth approximately $75 \mathrm{~cm}$ ), $\mathbf{C}$ residents' home in the Fares area, $\mathbf{D}$ dug hole showing groundwater uprising, $\mathbf{E}$ groundwater uprising inside residential houses, and $\mathbf{F}$ bridge of the Kalabsha Corridor is hindered by groundwater uprising (All photos were taken by Mohamed Saber, during the field survey on 2012)

drainage surface water to distinguish and identify the source of the leaching water. It was found that the seepage water characteristics are mostly similar to the groundwater well characteristics, which confirms that the uprising water in the lowlands (the affected regions) is mainly sourced from groundwater wells.

The recommended solution for reducing groundwater uprising is the construction of a surface drainage system that collects excessive water resulting from surface flood irrigation systems. These surface drainage systems may include land smoothing or grading, field ditches, and open drains or channels that provide an outlet for accumulated water (Ritter and Shirmohammadi 2001; Irwin 1997). The construction of subsurface drainage (tiles) will remove the excess water from the plant zone and lower the water table (Ritter and Shirmohammadi 2001). In addition, dewatering wells can reduce groundwater levels in lowland areas. The most important recommendation of this study is for both farmers and decision makers to use new irrigation systems, such as drip or sprinkler systems, instead of flood 


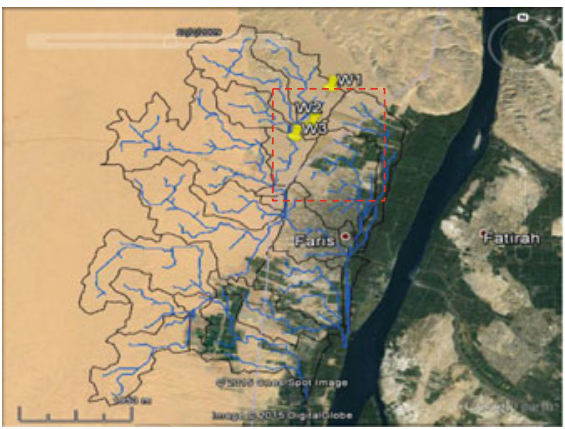

(a)

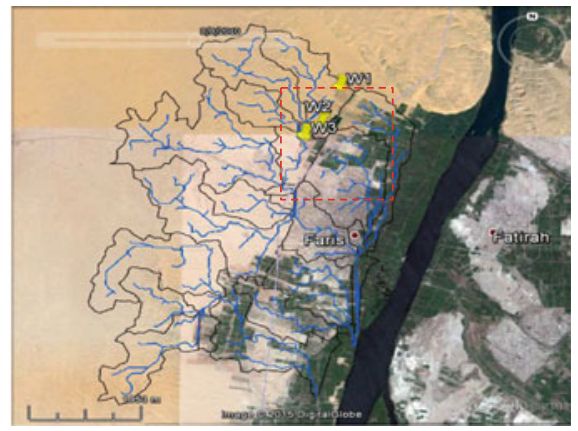

(b)

Fig. 22.3 Google maps of the target area from October 2009 (a) to August 2010 (b), showing the changes in reclamation areas that occurred within one year

Table 22.1 Chemical analysis of water samples collected from groundwater wells, the Nile River, and seepage water (uprising water)

\begin{tabular}{l|l|l|l|l|l}
\hline Parameter & $\begin{array}{l}\text { Surface (Nile } \\
\text { River) }\end{array}$ & $\begin{array}{l}\text { Seepage (uprising } \\
\text { groundwater) }\end{array}$ & $\begin{array}{l}\text { Well } \\
1\end{array}$ & Well 2 & Well 3 \\
\hline $\mathrm{pH}$ & 7.5 & 7.4 & 7.3 & 7.24 & 7.39 \\
\hline TDS & 152.3 & 1180.7 & 937.2 & 1297.56 & 1267.1 \\
\hline HCO4- & 116 & 300 & 190 & 220 & 209 \\
\hline $\begin{array}{l}\text { Total } \\
\text { hardness }\end{array}$ & 110 & 296 & 352.4 & 407.4 & 350 \\
\hline Calcium & 28.8 & 67.2 & 95.1 & 97 & 85 \\
\hline Magnesium & 9.12 & 30.7 & 27.9 & 39.6 & 33.5 \\
\hline Sulfate & 18 & 265.5 & 256.6 & 338.8 & 335 \\
\hline
\end{tabular}

irrigation systems, especially on newly reclaimed lands in the desert region. Consequently, the problem of groundwater level uprising would be solved, as well as the sustainable management of the available groundwater in the desert.

\subsection{Hydrogeochemical Characteristics}

High-quality water is of basic importance to human life and its existence (Lamikarna 1999). The chemistry of groundwater and its nexus to the dominant hydrogeological circumstances have been considered, especially in arid and semiarid regions. In this paper, we attempt to address the following issues regarding the hydrogeochemistry of the aquifer in the study region: the physical parameters of the 
groundwater, chemical parameters of the groundwater, groundwater types, hydrochemical profiles, and hydrochemical genetic classification.

\subsubsection{Methodology and Sampling}

Thirty-three groundwater samples were collected from three groundwater wells during the period of time from October 2011 to July 2013 and then analyzed for major ions $\left(\mathrm{Ca}^{++}, \mathrm{Mg}^{++}, \mathrm{Na}^{+}, \mathrm{HCO}_{3}{ }^{-}, \mathrm{SO}_{4}{ }^{--}\right.$, and $\left.\mathrm{Cl}^{-}\right)$, minor components $\left(\mathrm{Fe}^{++}\right.$, $\mathrm{Mn}^{++}, \mathrm{NH}_{3}, \mathrm{NO}_{2}{ }^{-}$, and $\left.\mathrm{NO}_{3}{ }^{-}\right)$, and trace elements $(\mathrm{Pb}, \mathrm{Cd}$, and $\mathrm{Cr}$ ). The techniques and methods followed for the collection and preservation of the samples were in accordance with the 20th edition of the Standard Methods of the American Public Health Association (1998).

\subsubsection{Physical Characteristics of Groundwater}

In the study area, the groundwater temperature ranges between $27.3{ }^{\circ} \mathrm{C}$ ( $\mathrm{min}$.) and $31.5^{\circ} \mathrm{C}$ (max.). The $\mathrm{pH}$ values of the collected groundwater samples ranged between 7 and 8.3 , which reflect that the water samples vary from neutral to slightly alkaline groundwater.

\subsubsection{Chemical Characteristics of Groundwater}

According to Faust and Aly (1981), natural groundwater contains many chemical species in the dissolved state. The occurrence of these constituents results from many physical and chemical weathering processes on geologic formations and from many chemical reactions. Furthermore, the nature of these constituents is a function of the geological type comprising the surrounding area. Glower (1983) reported that anthropogenic changes in groundwater are controlled by humanity's influence, geochemical, physical, and biological processes underground, and hydrogeological conditions.

\subsubsection{Electrical Conductivity}

The electrical conductivity in the study area ranges from 698.78 to $1966 \mu \mathrm{S} / \mathrm{cm}$. Figure 22.4a illustrates that the EC in Well 1 is lower than that in Well 2 and Well 3. As a result of intensive and prolonged agricultural practices (due to the overdrafting from this well as the farmers use surface flooding systems), the EC exhibits a linear increase from $698.78 \mu \mathrm{S} / \mathrm{cm}$ to $1420 \mu \mathrm{S} / \mathrm{cm}$ within approximately two years. 


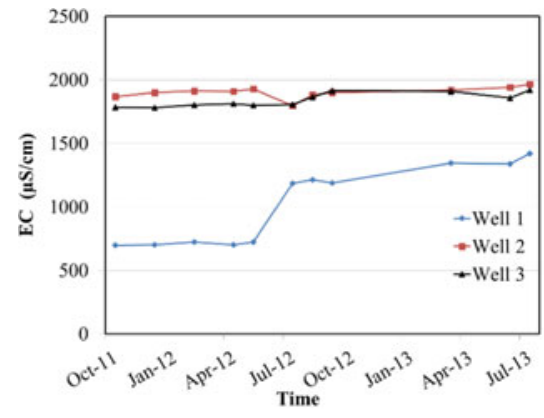

a

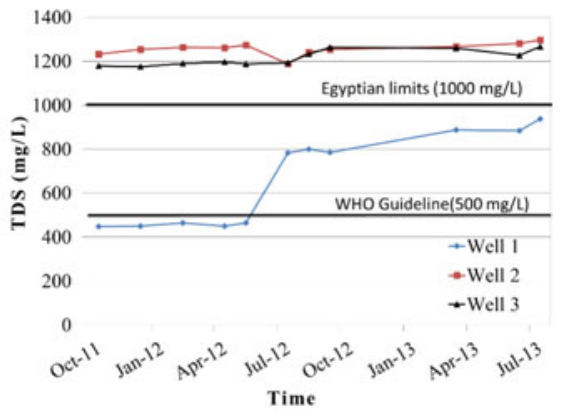

b

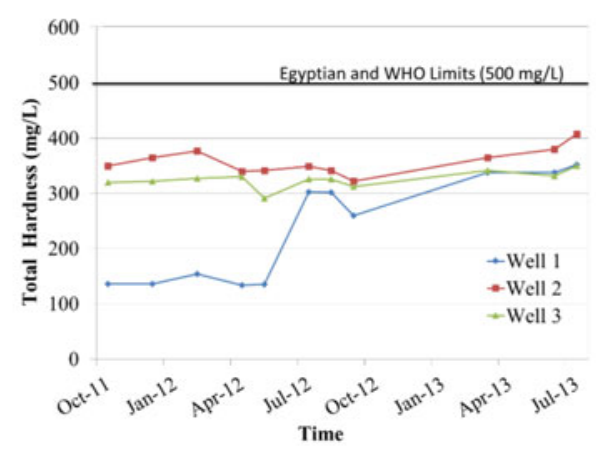

C

Fig. 22.4 a The EC values, $\mathbf{b}$ TDS values, and $\mathbf{c}$ total hardness values of the groundwater samples in the study area

\subsubsection{Total Dissolved Solids (TDS)}

Water with a high TDS level may taste salty and be corrosive, resulting in scale formation, which decreases the efficiency of hot water heaters (Sawyer and McCarty 1967). In the study area, the TDS values range from 447.22 to $1297.56 \mathrm{mg} / \mathrm{L}$ (Fig. 22.4b). In Well 2 and Well 3, the TDS concentrations are higher than the limits of the WHO and the Egyptian standards. Well 1 water shows a linear increase from acceptable levels to over-the-limit levels.

\subsubsection{Total Hardness}

The hardness of water mainly depends upon the amount of calcium or magnesium salts in the water or both (Rao 2011; Meena and Bhargava 2012). The total hardness concentrations of the sampled water range from 134 to $380 \mathrm{mg} / \mathrm{L}$ (Fig. 22.4c), indicating that the groundwater in the study area can be considered 
hard water to very hard water. Additionally, in Well 1, the total hardness of the water increases with time due to the overpumping of groundwater.

\subsubsection{Alkalinity}

The alkalinity of water is controlled by the presence of carbonate, bicarbonate, and hydroxide compounds of sodium, calcium, and potassium (Pandey and Pandey 2012). The alkalinity values range from 178 to $226 \mathrm{mg} / \mathrm{L}$. It was found that $85 \%$ of the groundwater samples have a total hardness greater than their total alkalinity, which indicates that the groundwater is characterized by permanent (non-carbonate) hardness (Chow 1964).

\subsubsection{Concentration of Major Ions}

The analyzed major cations are calcium $\left(\mathrm{Ca}^{2+}\right)$, magnesium $\left(\mathrm{Mg}^{2+}\right)$, sodium $\left(\mathrm{Na}^{+}\right)$, and potassium $\left(\mathrm{K}^{+}\right)$, and the major anions are carbonate $\left(\mathrm{CO}_{3}{ }^{2-}\right)$, bicarbonate $\left(\mathrm{HCO}_{3}{ }^{-}\right)$, chloride $\left(\mathrm{Cl}^{-}\right)$, and sulfate $\left(\mathrm{SO}_{4}{ }^{2-}\right)$. Regarding the calcium ion concentration, in the study area, the calcium concentrations range from 32.19 to $97 \mathrm{mg} / \mathrm{L}$ (Fig. 22.5a). The measured calcium concentrations in the three wells were within the acceptable limit, but Well 1 showed an increasing trend with time. The sodium concentration (Fig. 22.5b) ranges from 82 to $283 \mathrm{mg} / \mathrm{L}$. Well 1 shows strong changes with increasing trends due to the intensive and prolonged use of water for irrigation purposes, which led to an increase in the salinity of the well water. Wells 2 and 3 have high concentrations of sodium due to leaching processes. The magnesium concentrations in the groundwater range from 11.5 to $39.6 \mathrm{mg} / \mathrm{L}$ (Fig. 22.5c). Low values of magnesium ions were observed in Well 1, and high values were recorded in Wells 2 and 3; this may be attributed to the limestone plateau, which contains magnesium-bearing minerals.

In the study area, the potassium concentrations range between $2.7 \mathrm{mg} / \mathrm{L}$ and $10.19 \mathrm{mg} / \mathrm{L}$. The bicarbonate concentration in the groundwater ranges between $178 \mathrm{mg} / \mathrm{L}$ and $226 \mathrm{mg} / \mathrm{L}$. The sulfate concentrations range from 68 to $360 \mathrm{mg} / \mathrm{L}$. Well 1 shows low concentrations at the beginning of the analysis, and due to overdrafting, the sulfate concentration exceeded the limit of WHO standards. Wells 2 and 3 show high concentrations of sulfate because of the leaching processes of highly soluble sulfate-bearing minerals such as gypsum and anhydrite (Fig. 22.5d). Chloride concentrations in excess of approximately $250 \mathrm{mg} / \mathrm{L}$ can give rise to detectable tastes in water and cause laxative effects (Chand 1999). The chloride ion concentrations in the groundwater range from 63 to $356 \mathrm{mg} / \mathrm{L}$. In most groundwater samples containing high values of sodium, there is also a high concentration of chloride ions. The chloride concentrations of Wells 2 and 3 are higher than the WHO limits, and while the water in Well 1 is lower than the limit, there exists a threat of dramatic increases in concentrations within two years due to overpumping (Fig. 22.5e). 


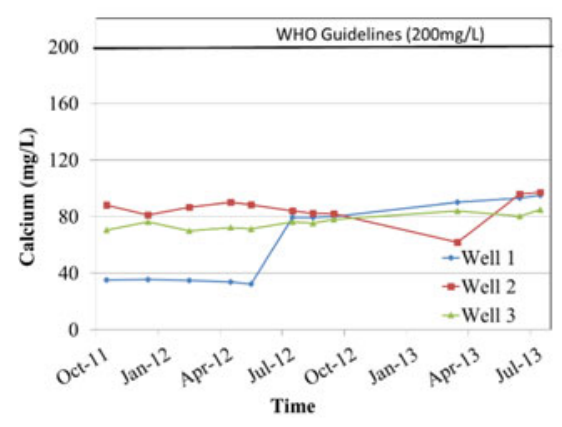

$\mathbf{a}$

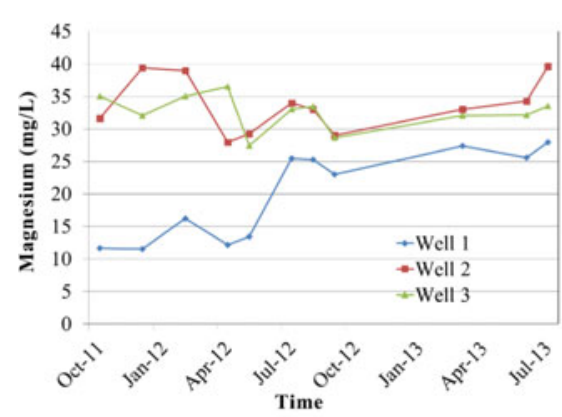

c

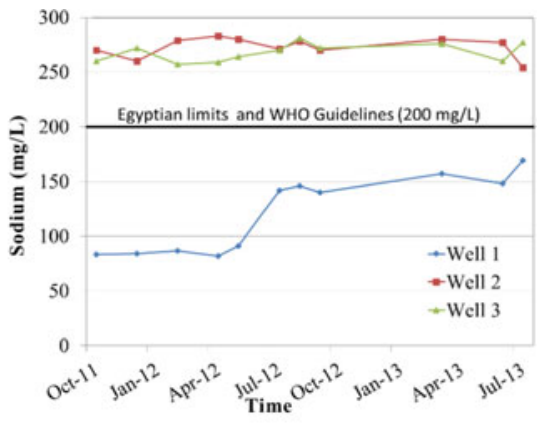

b

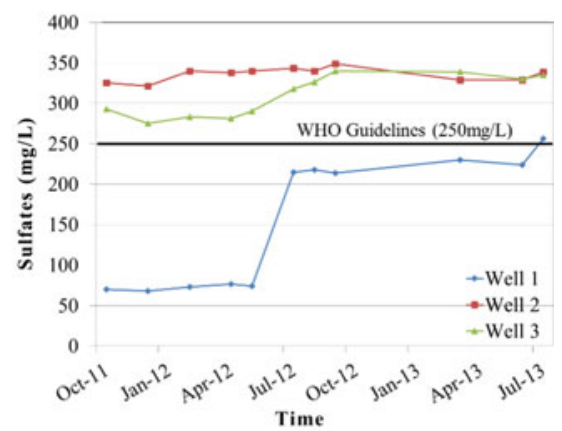

d

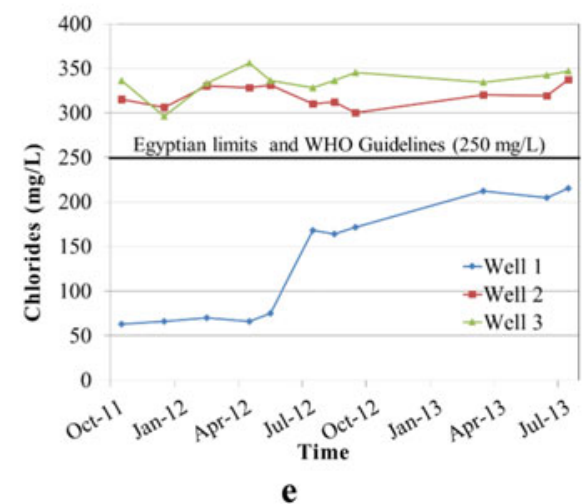

Fig. 22.5 a Calcium concentrations, b sodium concentrations, c magnesium concentrations, d sulfate concentrations, and e chloride concentrations in the groundwater samples in the study area

Iron occurs in the minerals hematite, magnetite, pyrite, and siderite. The recommended iron level by the United Nations Food and Agriculture Organization (FAO) for irrigation waters is $5 \mathrm{mg} / \mathrm{L}$ (American Public Health Association 1998). 
Based on the Secondary Drinking Water Standards and regulations recommended by The United States Environmental Protection Agency (EPA), the acceptable limit of Iron is $0.3 \mathrm{mg} / \mathrm{L}$ for drinking purposes. In the study area, the iron concentrations range between $0.01 \mathrm{mg} / \mathrm{L}$ and $0.1 \mathrm{mg} / \mathrm{L}$. The manganese ion concentrations range from $0.11 \mathrm{mg} / \mathrm{L}$ to $0.47 \mathrm{mg} / \mathrm{L}$.

\subsection{Water Types}

Classification methods are used to differentiate the chemical types of water and identify the dominant types. One of these methods is the Kurlov formula (Kurlov 1928), which is a very useful method for the primary characterization of the chemical composition of water. The ion dominance sequence in Well 1 changed from $\mathrm{HCO}_{3}{ }^{-}>\mathrm{Cl}^{-}>\mathrm{SO}_{4}{ }^{2-} / \mathrm{Na}^{+}>\mathrm{Ca}^{2+}>\mathrm{Mg}^{2+}$ to $\mathrm{Cl}^{-}>\mathrm{SO}_{4}{ }^{2-}>\mathrm{HCO}_{3}{ }^{-}$/ $\mathrm{Na}^{+}>\mathrm{Ca}^{2+}>\mathrm{Mg}^{2+}$ due to overdrafting withdrawal for flood irrigation. In Wells 2 and 3 , the abundant sequences for both cations and anions are steady and follow the order $\mathrm{Cl}^{-}>\mathrm{SO}_{4}{ }^{2-}>\mathrm{HCO}_{3}{ }^{-} / \mathrm{Na}^{+}>\mathrm{Ca}^{2+}>\mathrm{Mg}^{2+}$.

\subsection{Groundwater Genesis and Hydrochemical Facies}

\subsubsection{Hydrochemical Parameters}

The hydrochemical parameters are calculated by hydrogeochemical indicators such as ionic ratios. These ratios express the relationships between the different ions in terms of mathematical ratios, which are helpful in determining hydrochemical resemblances or differences among different water types. For instance, the ratios are useful in detecting the previous hydrochemical processes that have affected water quality, such as mixing, leaching, and ion exchange. In addition, such ratios may also be useful in distinguishing between groundwater having paleosalinity characteristics and mineralization characteristics resulting from evaporation processes or by seawater contamination.

The ionic concentrations in these ratios are calculated according to their equivalent concentrations (epm), and the ionic ratios are discussed. The value of $\mathrm{Na}^{+}+\mathrm{K}^{+} / \mathrm{Cl}^{-}$(meq/L), as a parameter, is very important, as it gives an indication of the genesis and origin of groundwater (marine or fresh water). In marine or seawater, this value ranges between 0.85 and 0.87 , while in fresh meteoric water, it is over one. The $\mathrm{Na}+\mathrm{K} / \mathrm{Cl}$ values in the study area range between $1.13 \mathrm{epm}$ and $2.09 \mathrm{epm}$, indicating that the groundwater samples are of meteoric origin. The ratio of sulfate to chloride $\left(\mathrm{SO}_{4}{ }^{2-} / \mathrm{Cl}^{-}\right.$(meq/l) is useful in determining any excess sulfate content in the groundwater due to the dissolution of sulfate minerals or sewage contamination. In the study area, it is obvious that all values of $\mathrm{SO}_{4}{ }^{2-} / \mathrm{Cl}^{-}$are less 
than one, and thus, chloride ions predominate. Low values of this ratio $\left(\mathrm{Ca}^{2+} / \mathrm{Mg}^{2+}\right.$ (meq/l)) indicate that the magnesium content exceeds the calcium content. However, high values of this ratio indicate the evaporative dissolution of gypsum and anhydrite or ion exchange. In the study area, all values of the ratio are more than one because the calcium ion concentration is more than that of magnesium ions, which indicates the leaching of calcium-rich sediments. The $\mathrm{Na}^{+} / \mathrm{K}^{+}(\mathrm{meq} / \mathrm{l})$ ratio gives an indication of the extent of the distance between the wells and the recharging sources. If the ratio is less than 50, the wells are near the recharge sources, and if the ratio is more than 50, the wells are far from the recharge sources. In the study area, most of the $\mathrm{Na}^{+} / \mathrm{K}^{+}$values of water in Well 1 are less than 50 , and this well is near its recharge sources (Fault). In Wells 2 and 3, the $\mathrm{Na}+/ \mathrm{K}+$ ratios are more than 50 due to the long distance between these wells and recharge sources. The ratio of $\mathrm{Cl}^{-} /$sum anions (meq/l) reflects the groundwater sources (Hounslow 2018). When the ratio is $>0.8$ and TDS $>500$, the source is seawater or brine, or evaporates; when the ratio is $>0.8$ and TDS $<100$, the source is rainwater; and when the ratio is $<0.8$ the source is rock weathering. This ratio is less than 0.8 in the groundwater samples of the study area. The standard values for seawater are $\mathrm{rK}^{+} / \mathrm{rCl}^{-}=0.0181, \quad \mathrm{rNa}^{+} / \mathrm{rCl}^{-}=0.8537, \quad \mathrm{rMg}^{2+} / \mathrm{rCl}^{-}=0.1986 \quad$ and $\mathrm{rSO}_{4}{ }^{2-} /$ $\mathrm{rCl}^{-}=0.103$ (Ovchinnikov 1955). According to this method, approximately $85 \%$ of samples belong to deep meteoric origin, and $15 \%$ belong to shallow meteoric origin.

\subsubsection{Hydrochemical Classification}

Different methods have been suggested for the chemical classification of groundwater. The trilinear diagram of Piper (1944) is one of the most widely used graphical methods for the classification of natural waters. In the study area, the plotting results of the chemical analysis of the groundwater samples over a period of time illustrate that sodium ions represent the main dominant cations, while chloride ions represent the dominant anions. This reflects that most groundwater samples have sodium chloride facies (Fig. 22.6). In addition, the water type in Well 1 changed from sodium bicarbonate to sodium chloride. This might be attributed to the impact of overdrafting withdrawal from this well.

According to the semilogarithmic diagram (Schoeller 1962), based on the plotted chemical analyses of the groundwater for the periods 10/2011, 7/2012, and 7/2013, the following patterns are recognized. In Well 1, the pattern changed from $\mathrm{HCO}_{3}{ }^{-}>\mathrm{Cl}^{-}>\mathrm{SO}_{4}{ }^{2-} / \quad \mathrm{Na}^{+}>\mathrm{Ca}^{2+}>\mathrm{Mg}^{2+}$ to $\mathrm{Cl}^{-}>\mathrm{SO}_{4}{ }^{2-}>\mathrm{HCO}_{3}{ }^{-}$/ $\mathrm{Na}^{+}>\mathrm{Ca}^{2+}>\mathrm{Mg}^{2+}$, which means that the groundwater chemistry changed from $\mathrm{NaHCO} 3$ to $\mathrm{NaCl}$. However, in the other two wells, the main patterns are $\mathrm{Cl}^{-}>\mathrm{SO}_{4}{ }^{2-}>\mathrm{HCO}_{3}{ }^{-} / \mathrm{Na}^{+}>\mathrm{Ca}^{2+}>\mathrm{Mg}^{2+}$, where $\mathrm{Na}^{+}$and $\mathrm{Cl}^{-}$are the dominant ions.

Based on Stiff diagrams (1951), in 10/2011, we found that the alkali contents $\left(\mathrm{Na}^{+}+\mathrm{K}^{+}\right)$were higher than the alkaline earth contents $\left(\mathrm{Ca}^{2+}+\mathrm{Mg}^{2+}\right)$, and the 

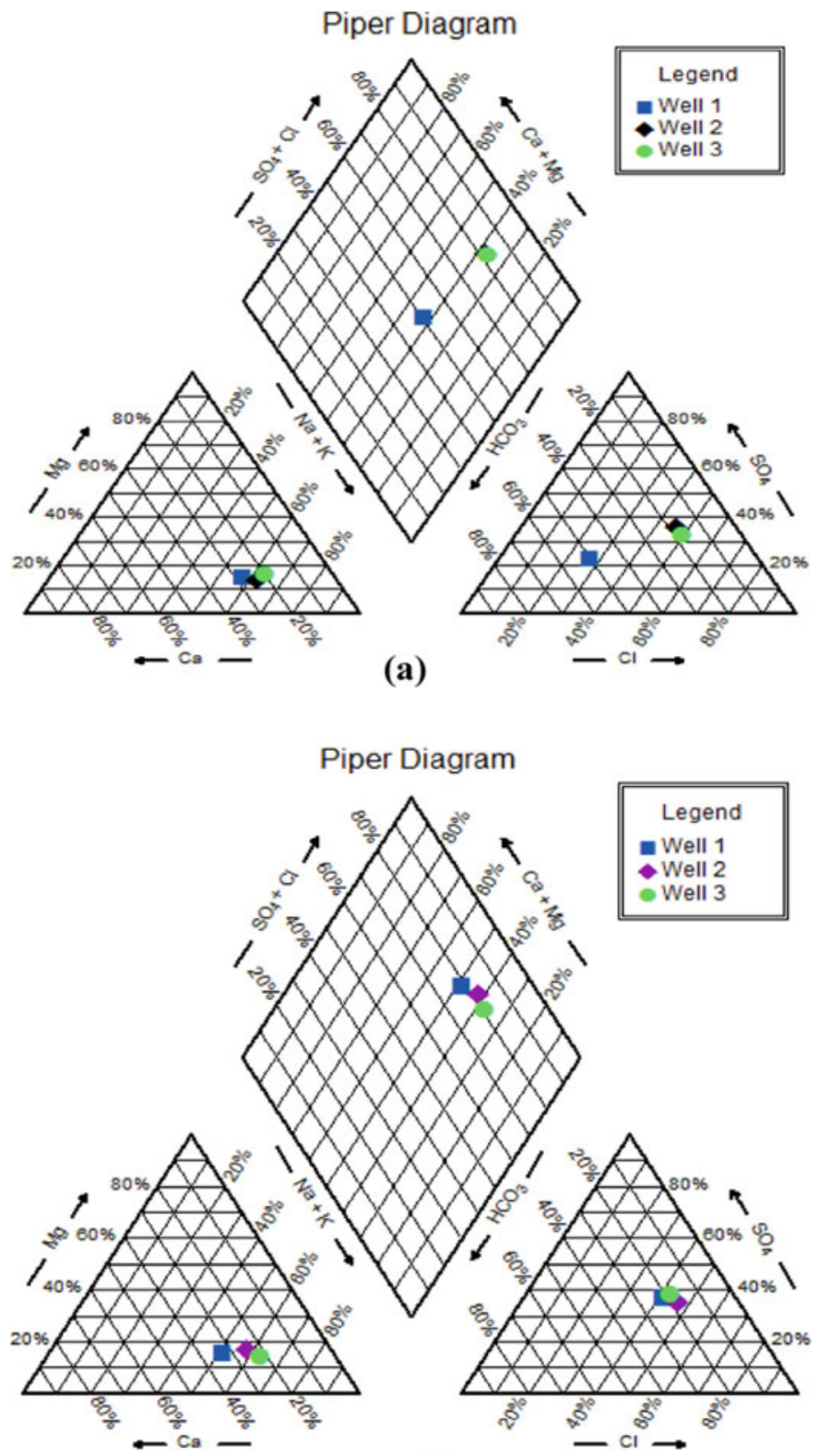

(b)

Fig. 22.6 Piper trilinear diagrams in 10/2011 (a) and 7/2013 (b) showing the changes in chemistry of water in Well 1 (green square) due to the impact of overdrafting withdrawal 
strong acid contents $\left(\mathrm{Cl}^{-}+\mathrm{SO}_{4}{ }^{2-}\right)$ were higher than the weak acid contents $\left(\mathrm{CO}_{3}{ }^{2-}+\mathrm{HCO}_{3}{ }^{-}\right)$in Wells 2 and 3. However, in Well 1, weak acids $\left(\mathrm{CO}_{3}{ }^{2-}+\mathrm{HCO}_{3}{ }^{-}\right)$were more abundant than strong acids $\left(\mathrm{Cl}^{-}+\mathrm{SO}_{4}{ }^{2-}\right)$. In $7 / 2012$ and $7 / 2013$, all groundwater samples were characterized by the abundance of chloride ions and sodium ions.

\subsection{Future Prediction of Water Quality}

The previous chemical characterization and analysis revealed that the chemistry of groundwater in Well 1 changed from one phase to another phase due to the impact of overpumping. Therefore, we attempt in this part to discuss and determine the future circumstances of the groundwater of this well. The analyzed data collected during the period of time from October 2011 to June 2013 are used to estimate the linear trends of several chemical parameters at Well 1. We estimated the predicted changes in the chemical characteristics of the groundwater. The TDS values at Well 1 increased with time from $447.2 \mathrm{mg} / \mathrm{L}$ to $937.2 \mathrm{mg} / \mathrm{L}$ (Fig. 22.7a). Based on the trend line, we expect that the TDS level after 3.3 months (69 days, at 10/2013) will exceed the standard limit $(1000 \mathrm{mg} / \mathrm{L})$ of TDS according to the Egyptian Standard of 2007. The TH values at Well 1 also increased with time by a rate of approximately $0.88 \mathrm{mg} / \mathrm{L} / \mathrm{month}$ (Fig. $22.7 \mathrm{a}$ ), indicating that after 17.1 months (513 days, at $12 / 2014)$, it will exceed the standard limit $(500 \mathrm{mg} / \mathrm{L})$. The sodium $(\mathrm{Na}+)$ concentrations increased at a rate of approximately $0.144 \mathrm{mg} / \mathrm{L} / \mathrm{month}$ (Fig. 22.7b), indicating that after 10.4 months (nearly at 5/2014), the sodium $(\mathrm{Na}+)$ concentrations will become over the limit $(200 \mathrm{mg} / \mathrm{L})$. The calcium $\left(\mathrm{Ca}^{++}\right)$concentrations increased with a linear trend rate of approximately $0.144 \mathrm{mg} / \mathrm{L} / \mathrm{month}$ (Fig. 22.7b), indicating that after 42.2 months (approximately 3.5 years, at $1 / 2017$ ), the $\mathrm{Ca}^{++}$ value will cross the maximum contaminant limit $(200 \mathrm{mg} / \mathrm{L})$. The magnesium $\left(\mathrm{Mg}^{++}\right)$concentration increased with a linear trend rate of approximately $0.028 \mathrm{mg} /$ L/month (Fig. 22.7b), revealing that after 202.7 months (approximately 17 years, at 10/2030), it will cross the maximum contaminant limit $(150 \mathrm{mg} / \mathrm{L})$. The chloride $\left(\mathrm{Cl}^{-}\right)$concentrations increased with a linear trend rate of approximately $0.28 \mathrm{mg} / \mathrm{L} /$ month (Fig. 22.7b), indicating that after 6 months (nearly 1/2014), the chloride concentrations will exceed the maximum contaminant limit $(250 \mathrm{mg} / \mathrm{L})$. The sulfate $\left(\mathrm{SO}_{4}{ }^{2-}\right)$ concentration increased with a linear trend rate of approximately $0.33 \mathrm{mg} /$ L/month (Fig. 22.7b), indicating that after 34 months (approximately 3 years, at 7/ 2016), it will exceed the $500-\mathrm{mg} / \mathrm{L}$ limit. It was found that there are dramatic changes in the quality of the groundwater of Well 1, showing a noticeable increase in parameter values from acceptable values to values over standard limits, resulting in quality deterioration in the near future, within a few years. This may be attributed to the overdrafting of groundwater from this well for agricultural activities, as inhabitants of the area use flooding systems in irrigation. 


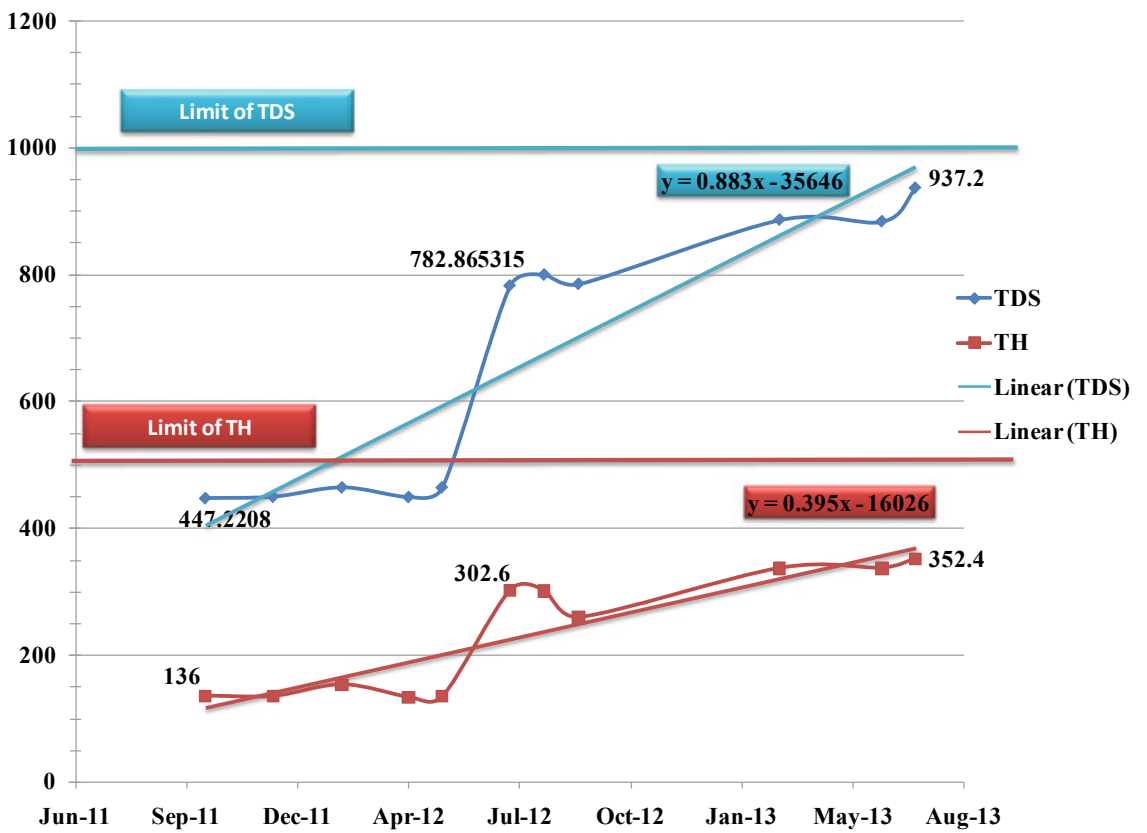

(a)

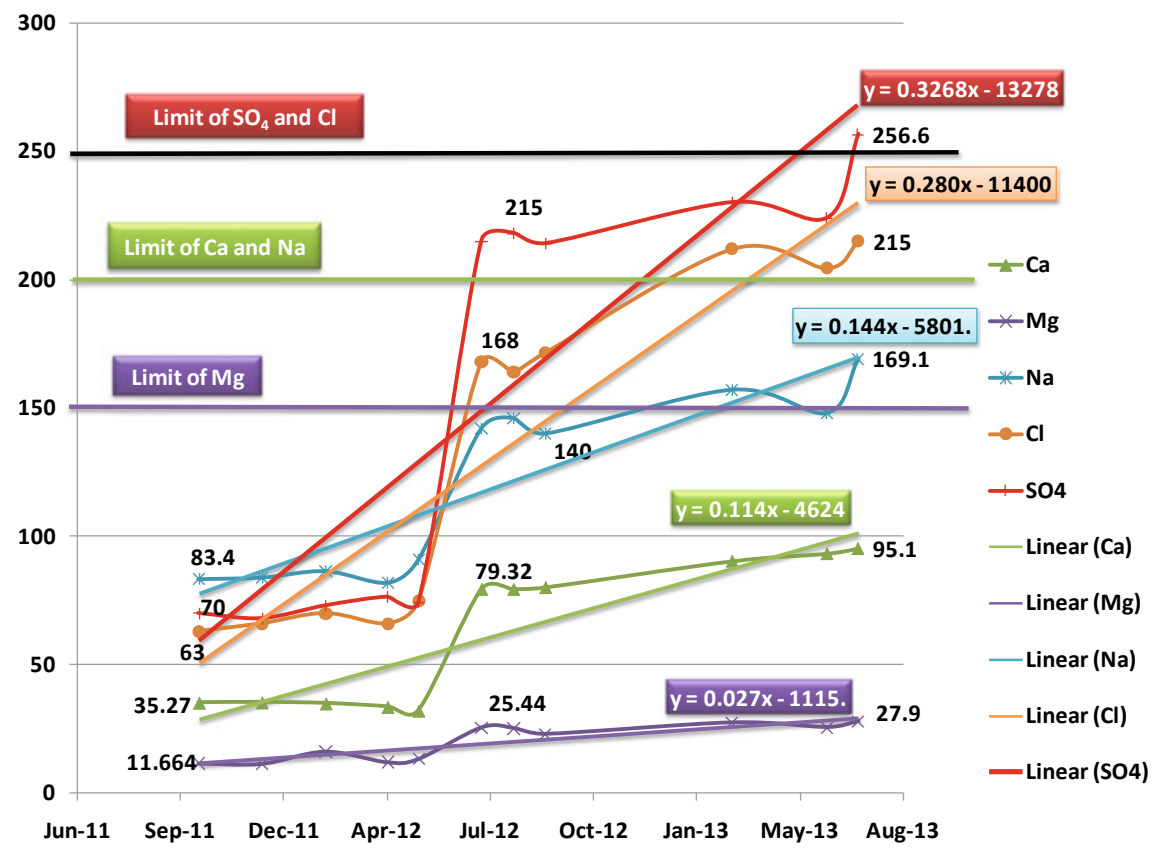

(b) 
4Fig. 22.7 a The linear trends of TDS and TH in the water of Well 1, and $\mathbf{b}$ the linear trends of $\mathrm{Ca}^{++}, \mathrm{Mg}^{++}, \mathrm{Na}^{+}, \mathrm{Cl}^{-}$and $\mathrm{SO}_{4}{ }^{-}$in the water of Well 1

\subsection{Bacteriological Analysis of Groundwater}

It is well known that the main threat to human health related to drinking water is microbial contamination. A risk assessment of pathogens and chemicals in drinking water concluded (Regli et al. 1993) that the risk of death from known pathogens in untreated water is 100 to 1000 times greater than the risk of cancer from known disinfection byproducts in chlorinated drinking water, and that the risk of illness from pathogens is 10,000 to $1,000,000$ times greater than the risk of cancer from disinfection byproducts in chlorinated drinking water; if the water treatment is inadequate, or if the water distribution system is inadequate, drinking water may contain sufficient numbers of pathogens to cause illness (O'Connor 2000). These pathogenic microorganisms can cause diseases, and the detection of these organisms such as dysentery and typhoid may take long time; in addition, special equipment is required for these detections. For a long time, public health officials/ scientists assessed water quality by enumerating fecal coliform and E. coli levels in rivers, estuaries, lakes, and coastal waters (Malakoff 2002; Pandey et al. 2012; Pandey and Soupir 2013). Water that is free of coliform bacteria gives an indication of the validity of that water for human consumption bacteriologically. In contrast, the presence of these bacteria in water is considered proof of pollution and results in the disqualification of that water for drinking. The prevention of waterborne diseases lowers the disease burden in developing countries and improves health, leading to poverty reduction.

In the study area, groundwater samples were collected at different times: 12/ $2011,8 / 2012,3 / 2013$, and 7/2013. These water samples were analyzed for total heterotrophic bacteria (THB), total coliform, and fecal coliform levels. The spread plate technique was employed to enumerate the bacteria, and the total number of heterotrophic bacteria was determined using nutrient agar medium. The most likely number (MPN) method was employed for the total and fecal coliform levels. In drinking water, total coliform and E. coli should be absent (WHO 1994), so water from most sources is unfit for immediate consumption without some sort of treatment (Raymond 1992). The bacteriological quality of the sampled groundwater samples indicated the absence of total heterotrophic bacteria and total and fecal coliform bacteria, which means that groundwater samples are negative (free from biological contamination) because the aquifer is far enough from the urban area and exists in highlands in the desert. 


\subsection{Conclusions}

In this study, chemical and biological analyses of groundwater aquifers were carried out, in addition to environmental investigations of the impacts of the uprising groundwater level in the target area. The environmental impacts of the uprising groundwater level were discussed and confirmed by watershed analysis using DEM and GIS techniques and by chemical analyses of water samples from uprising water, groundwater wells, and the Nile River water in order to determine the water source and the reason for the uprising water in the low-lying regions. We found that the use of flood irrigation systems in the upper, newly reclaimed lands (in the desert), lakes in agricultural drainage systems, and the absence of sewage networks are the main causes of uprising groundwater levels. Therefore, it is recommended that the use of flood irrigation systems is stopped and that another, new technology system for irrigation is used, in addition to constructing sewage and drainage systems in the whole city area.

A chemical analysis of the groundwater aquifer in the Fares area was conducted and showed that the groundwater in the study area has normal physical properties wherein the water samples varied from neutral to slightly alkaline groundwater. The TDS values ranged from 447.22 to $1297.56 \mathrm{mg} / \mathrm{l}$. It was obvious that water from Well 1 had lower concentrations of TDS than did the waters in the other two wells (Wells 2 and 3). The calcium concentrations ranged from 32.19 to $97 \mathrm{mg} / \mathrm{L}$, the magnesium concentrations ranged from 11.5 to $39.6 \mathrm{mg} / \mathrm{L}$ and the total concentrations of sodium and potassium ranged from 84.8 to $292 \mathrm{mg} / \mathrm{L}$. The bicarbonate concentrations ranged from 178 to $226 \mathrm{mg} / \mathrm{L}$, the sulfate concentrations ranged from 68 to $360 \mathrm{mg} / \mathrm{L}$, and the chloride concentrations ranged from 63 to $356 \mathrm{mg} / \mathrm{L}$. Most groundwater samples contained high values of sodium and chloride ions. The most important finding from the chemical analysis is that there were dramatic changes observed in the water quality of Well 1 groundwater, showing a noticeable increase in parameter values from acceptable values to values over standard limits, resulting in quality deterioration in the near future within a few years. This may be attributed to the overdrafting of groundwater from this well for agricultural activities, as inhabitants of the area use flooding systems in irrigation.

Different methods were suggested for the chemical classification of groundwater such as the trilinear diagram of Piper, semilogarithmic diagrams (Schoeller), and Stiff diagrams. They illustrated that sodium ions represent the main dominant cations, while chloride ions are considered the dominant anions. This reflects that most groundwater samples have sodium chloride facies. In addition, the water type in Well 1 changed from sodium bicarbonate to sodium chloride. This might be attributed to the impact of overdrafting withdrawal from this well. The chemical patterns in Well 1 changed from $\mathrm{HCO}_{3}{ }^{-}>\mathrm{Cl}^{-}>\mathrm{SO}_{4}{ }^{2-} / \mathrm{Na}^{+}>\mathrm{Ca}^{2+}>\mathrm{Mg}^{2+}$ to $\mathrm{Cl}^{-}>\mathrm{SO}_{4}{ }^{2-}>\mathrm{HCO}^{-} / \mathrm{Na}^{+}>\mathrm{Ca}^{2+}>\mathrm{Mg}^{2+}$, which means that the groundwater chemistry changed from $\mathrm{NaHCO} 3$ to $\mathrm{NaCl}$. However, in the other two wells, the main patterns are $\mathrm{Cl}^{-}>\mathrm{SO}_{4}{ }^{2-}>\mathrm{HCO}_{3}{ }^{-} / \mathrm{Na}^{+}>\mathrm{Ca}^{2+}>\mathrm{Mg}^{2+}$, wherein $\mathrm{Na}^{+}$and $\mathrm{Cl}^{-}$were the dominant ions. The groundwater origin samples show that all of the 
collected groundwater samples are of meteoric origin. A total of $85 \%$ of the samples belong to deep meteoric origins, and $15 \%$ belong to shallow meteoric origins.

Furthermore, a microbiological analysis of the groundwater of the study area was carried out, showing negative results, which means that the groundwater in the study area is free from pathogenic organisms because the wells are far from urbanization areas. Based on this study, we recommend that the people and governorate in Aswan City, Egypt, control and manage the use of groundwater from these wells because the current research states that the quality of the wells will dramatically decrease within the next few years. Additionally, further groundwater modeling analyses regarding the problem of groundwater uprising in the target city constitute our near-future research.

Acknowledgements This work was funded by the TEMPUS Project of Applied Environmental Geosciences and Water Resources Management (JEP-32005-2004), Assiut University, Egypt.

\section{References}

Abd El-Razik T, Razavaliaev A (1972) On the tectonic origin of the Nile Valley between Idfu and Qena, Egypt. J Geol 16-2:235-245

American Public Health Association (1998) Standard Methods for the examination of water and waste water, 20st Ed., Washington, DC. (1998)

Aydin (2007) The microbiological and physico-chemical quality of groundwater in West Thrace, Turkey. Pol J Environ Stud 16(3):377

Balachandar D, Sundararaj P, Rutharvel MK, Kumaraswamy K (2010) An investigation of groundwater quality and its suitability to irrigated agriculture in Coimbatore District, Tamil Nadu, India-A GIS approach. Int J Environ Sci 1(2):176-190

Briancesco R (2005) Microbial indicators and fresh water quality assessment. A IST Super Sanita 41:353

Chand D (1999) Fluoride and human health-causes in concern. Indian J Environ Protec 19(2):8189

Chow (1964) Handbook of Applied Hydrology. McGraw-Hill Book Company

Corapcioglu MY, Haridas A (1984) Transport and fate of microorganisms in porous media: a theoretical investigation. J Hydrol 72:149-169

Craun GE (1984) Health aspects of groundwater pollution. In: Bitton G, Gerba CP (eds) Groundwater pollution microbiology. John Wiley \& Sons, Inc., New York, pp 135-179

Dhiviyaa PTS, Venkatesa RT, Punithavathi L, Karunanithi S, Bhaskaran A (2011) Groundwater pollution in the palar riverbed near Vellore, Tamil Nadu, India. Indian J Sci Tech 4-1:19-21

Domenico PA, Schwartz FW (1990) Physical and chemical hydrogeology. Wiley, New York, pp 410-420

Dougerty TC, Hall AW, Wallingford HR (1995) Environmental impact assessment of irrigation and drainage projects

EGPC and Conoco (1977) Aeromagnetic anomaly map of southern Egypt; scale 1:500,000 Complied by the "La Compagnie General De Geophysique" Cairo, Egypt

EGPC and Conoco (1987) Geological map of Egypt, Scale 1:500,000 Cairo, Egypt

Emberger L (1951) Raoirtsur les regions arideset semi-arides de L'Afrique due Nord, les bases ecologiques de la regeneration de la vegetation des zone arides. Internet Urion Biol Sci Ser B Paris 9:50-61 
Faust SD, Aly OM (1981) Chemistry of natural waters published by Ann Arbor Science, Michigan, 400

Fenwick A (2006) Waterborne-Could they be consigned to History? Science 313:1077-1081

Freeze RA, Cherry JA (1979) Groundwater. Prentice-Hall, Englewood Cliffs, NJ, USA

Gerba CP, Keswick BH (1981) Survival and transport of enteric viruses and bacteria in groundwater. In: van Duijvenbooden W, Glasbergen P, van Lelyveld H (eds) Studies in environmental science. Elsevier Scientific Publ. Co., The Netherlands, pp 511-515

Glower A (1983) Underground purification capacity. Groundwater in water resources planning published by International Association of Hydrogeologists, UNISCO. Federal republic of Germany, vol 2, pp 1063-1072

Hakim MA, Juraimi AS, Begum M, Hasanuzzaman M, Uddin MK (2009) Suitability evaluation of groundwater for irrigation, drinking and industrial purposes. Am J Environ Sci 5:413-419

Hounslow AW (2018) Water quality data-analysis and interpretation. CRC Press LLC, 85

IPCC (2001) Climate change 2001: the scientific basis. In: Houghton JT, Ding Y, Griggs DJ, Noguer M, van der Linden PJ, Dai X, Maskell K, Johnson CA (eds) Contribution of working group $\mathrm{I}$ to the third assessment report of the intergovernmental panel on climate change. Cambridge University Press, Cambridge, United Kingdom and New York, NY, USA, 881pp

Irwin RW (1997) Handbook of drainage principles, publication 73. Toronto ON. Ontario Ministry of Agriculture, Food and Rural Affairs

Jain CK, Bandyopadhyay A, Bhadra A (2009) Hydrochemical appraisal of groundwater and its suitability in the intensive agricultural area of Muzaffarnagar district, Uttar Pradesh, India. Environ Geol 56:901-912

Kortatsi BK (2007) Hydrochemical framework of groundwater in the Ankobra Basin, Ghana. Aquat Geochem 13(4):1-74

Kurlov M (1928) Classification of mineral waters of Siberia, Tomsk, U.S.S.R.

Lamikarna A (1999) Essential microbiology for student and practitioner of Pharmacy, Medicine and Microbiology, 2nd edn, Amkra books Lagos, p 406

Liu L, Johnson HL, Cousens S, Perin J, Scott S, Lawn JE, Rudan I, Campbell H, Cibulskis R, Li M, Mathers C, Black RE (2012) Child health epidemiology reference group of WHO and UNICEF. Global, regional, and national causes of child mortality: an updated systematic analysis for 2010 with time trends since 2000. Extern Web Site Icon Lancet 379(9832):

Malakoff D (2002) Water quality: microbiologists on the trail of polluting bacteria. Science 4 (5564):

Meena BS, Bhargava N (2012) Physiochemical characteristics of groundwater of some villages of Dag Block in Jhalawar district of Rajasthan State (India). Rasayan J Chem 5(4):438-444

Ministry of Water Resources and Irrigation (MWRI) (2007) The final technical report - the results of the groundwater potential study in the desert alternative housing project in Aswan-Urgent Plan-The new Fares, The New Elramady and The New Allaqi

Mitra BK, Sasaki C, Enari K, Matsuyama N, Pongpattanasiri S (2007) Suitability assessment of shallow groundwater for irrigation in sand dune area of northwest Honshu Island, Japan. Int $\mathbf{J}$ Agric Res 2:518-527

Nagarajan R, Rajmohan N, Mahendran U, Senthamilkumar S (2010) Evaluation of groundwater quality and its suitability for drinking and agricultural use in Thanjavur city, Tamil Nadu, India. Environ Monit Assess 171:289-308

Nickson RT, McArthur JM, Shrestha B, Kyaw-Nyint TO, Lowrt D (2005) Arsenic and other drinking water quality issues, Muzaffargarh District, Pakistan. Appl Geochem 20:55-68

O'Connor DR (2002) Report of the Walkerton Inquiry - Part 1. Events of May 2000 and Related Issues: Queen's Printer for Ontario

Ovchinnikov AM (1955) General hydrogeology. USSR, Moscow

Pandey R, Pandey SK (2012) Investigations of physico-chemical status of ground water of Singrauli District, Madhya Pradesh, India. Int J Pharmac Sci Res 3(10):

Pandey PK, Soupir ML (2013) Assessing the impacts of E. coli laden streambed sediment on E. coli loads over a range of flows and sediment characteristics. J Am Water Resour Assoc 4 (6):1261-1269 
Pandey PK, Soupir ML, Rehmann CR (2012) A model for predicting resuspension of Escherichia coli from streambed sediments. Water Res 4:115-126

Pedley S, Howard G (1997) The public health implication of groundwater microbiology. Q J Eng Geol 30(2):179

Piper AM (1944) A graphic procedure in geochemical interpretation of water analysis. Trans Amer Geophys Union 25:914-928

Rao VB (2011) Physicochemical analysis of selected ground water samples of Vijayawada rural and urban in Krishna district, Andhra Pradesh, India. Int J Environ Sci 2(2):722-726

Raymond FL (1992) Problame dis eandans le monde (problems of water). EB and Sons Ltd., UK, pp 123-126

Regli S, Berger P, Macler B, Haas C (1993) Proposed decision tree for management of risks in drinking water: Consideration for health and socioeconomic factors. In: Craun GF (ed) Safety of water disinfection: balancing chemical and microbial risks. ILSI Press, Washington DC

Reid DC, Edwards AC, Cooper D, Wilson E, Mcgaw BA (2003) The quality of drinking water from private water supplies in Aberdeenshire, UK. Wat Res 37:245

Ritter WF, Shirmohammadi A (2001) Agricultural nonpoint source pollution. Watershed management and hydrology. CRC Press LLC, Florida

Saber M, Abdelshafy M, Faragallah ME, Abd-Alla MH (2014) Hydrochemical and bacteriological analyses of groundwater and its suitability for drinking and agricultural uses at Manfalut District, Assuit, Egypt. Arab J Geosc 7(11):. https://doi.org/10.1007/s12517-013-1103-2

Said R (1962) The geology of Egypt. El Sevier, Amsterdam New York

Said R (1981) The geological evaluation of the River Nile. Springer Verlage, New York, p 151

Sawyer CN, McCarty PL (1967) Chemistry for sanitary engineers, 2nd edn, McGraw-Hill Series in Sanitary Science and Water Resources Engineering. McGraw-Hill, Toronto

Schoeller H (1962) Geochemie des eauxsouterraines. Rev. de I' Institute Francais du Petrole $10: 230-244$

Shalaby MY (2005) Educational requirements for young graduates for modern irrigation systems on New Lands-Nubaria. Res Bull Soc Protect Environ Rural East Reg 2(2)

Stiff H (1951) The interpretation of chemical water analysis by means of patterns. J Petrol Tech 3:15-17

Trivedy RK, Goel PK, Trishul CL (1987) Practical methods in ecology and environmental science. Environmental Publication, Karad

UNESCO (2000) Groundwater pollution, international hydrological programme

United Nations Environmental Program (UNEP) (1999) Global Environmental outlook 2002. Earthscan, UK.

Usharani K, Umarani K, Ayyasamy PM, Shanthi K, Lakshmanaperumalsamy P (2010) Physico-chemical and bacteriological characteristics of noyyal river and ground water quality of Perur, India. J Appli Sci Environ Manag 14(2):29-35

WHO (1994) Guidelines for Drinking Water Quality, 2nd edn. World Health Organization, Geneva

WHO (2004) Guidelines for drinking-water quality, vol 1. Recommendations, 3rd ed. Geneva, Switzerland

WHO/UNICEF (2012) Progress on drinking water and sanitation: 2012 Update. External Web Site Icon United States: WHO/UNICEF Joint Monitoring Programme for Water Supply and Sanitation 
Open Access This chapter is licensed under the terms of the Creative Commons Attribution 4.0 International License (http://creativecommons.org/licenses/by/4.0/), which permits use, sharing, adaptation, distribution and reproduction in any medium or format, as long as you give appropriate credit to the original author(s) and the source, provide a link to the Creative Commons license and indicate if changes were made.

The images or other third party material in this chapter are included in the chapter's Creative Commons license, unless indicated otherwise in a credit line to the material. If material is not included in the chapter's Creative Commons license and your intended use is not permitted by statutory regulation or exceeds the permitted use, you will need to obtain permission directly from the copyright holder.

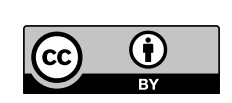

